\title{
Implementasi Undang - Undang Nomor 6 Tahun 2014 Tentang Desa (Studi Pada Desa Massamaturu Kecamatan Polongbangkeng Utara Kabupaten Takalar)
}

\author{
Sahrul ${ }^{1}$, Mustari ${ }^{2}$ \\ ${ }^{1}$ Ilmu Pengetahuan Sosial, SMP Negeri 4 Mappakasunggu, Indonesia \\ e-mail: arultola83@gmail.com \\ ${ }^{2}$ Program Pascasarjana Jurusan Ilmu Pengetahuan Sosial, Universitas Negeri Makassar \\ e-mail: mustari6508@unm.ac.id
}

\begin{abstract}
Abstrak. Tujuan penelitian ini adalah untuk mengetahu pola pembangunan di desa Massamaturu sebagai realisasi UU No.6 Tahun 2014 dalam penanggulangan kemiskinan terkait pembangunan desa, untuk mengetahui pelaksanaan UU No.6 Tahun 2014 terkait pembangunan desa tentang dampak terhadap penaggulangan kemiskinan di desa Massamaturu dan untuk mengetahui faktor penentu dalam penaggulangan kemiskinan di desa Massamaturu melalui pelaksanaan UU No.6 Tahun 2014 terkait pembangunan desa. Penelitian ini adalah penelitian mengunakan kualitatif deskriptif. Metode pengumpulan data melalui observasi, wawancara, dan dokumentasi serta analisi data yang dilakukan reduksi data, penyajian data, dan penarikan kesimpulan. Hasil penelitian menunjukan bahwa pola pembangunan yang dilaksanakan di desa Massamaturu mengunakan pola pembangunan yang bersifat bottom - up yang dibuat berdasarkan kebutuhan, keinginan dan permasalahan yang muncul di masyarakat kemudian di akomodasi pemerintah daerah maupun pusat sebagai mata program dalam perencanaan pembangunan yang ada di Desa. Penanggulangan kemiskinan di desa Massamaturu merujuk pada kondisi, karakteristik dan kebutuhan masyarakat dengan program-program yang meliputi Prudes, badan usaha milik Desa, Embung Desa dan raga Desa. Pelaksanaan UU No.6 Tahun 2014 pasal 78 ayat (1) berdampak positif dan penurunan angka kemiskinan pertahun turun 3-4\% dengan merealisasikan kebijakan-kebijakan yang lebih mengarahkan kepada kesejahtraan masyarakat dengan program memberikan pelatihan menjahit, penyuluhan pertaniaan, membagikan bibit unggul, memberikan alat pertukangan dan pertanian bagi kelompok tani yang ada di desa dan dapat dirasakan bagi semua masyarakat dengan baik. Faktor pendukung dalam penaggulangan kemiskinan di desa Massamaturu di antaraya: arah kebijakan pembangunan desa, perencanaan pembangunan desa, starategi pembangunan desa dan starategi pencapaian pembagunan desa (bidang ekonomi, pertanian, pendidikan, kesehatan, sarana prasarana, pemerintahan dan kerohanian). Faktor penghambat sumber daya manusia masih rendah karena mayoritas penduduk desa Massamaturu adalah petani.
\end{abstract}

Kata kunci: Undang-undang desa, Pembangunan, Kemiskinan

Abstract. The purpose of this study was to find out the pattern of development in Massamaturu village as the realization of Law No. 6/2014 on poverty reduction related to rural development, to find out the implementation of Law No. 6 of 2014 concerning village development regarding the impact on poverty reduction in Massamaturu village and to find out determinant in poverty alleviation in Massamaturu village through the implementation of Law No. 6 of 2014 concerning village development. The results 
showed that the pattern of development carried out in the village of Massamaturu used a bottom-up pattern of development based on needs, desires and problems that emerged in the community and then accommodated by the regional and central government as a program in the development planning in the village. Poverty reduction in Massamaturu village refers to the conditions, characteristics and needs of the community with programs that include Prudes, business entities belonging to the Village, Village Embung and Village Body. The implementation of Law No. 6 of 2014 article 78 paragraph (1) has a positive impact and decreases the annual poverty rate by $3-4 \%$ by realizing policies that are more directed towards the welfare of the community by providing sewing training, agricultural counseling, sharing superior seeds, carpentry and agricultural tools for farmer groups in the village and can be felt by all communities well. Supporting factors in poverty alleviation in Massamaturu village include: the direction of village development policies, village development planning, village development strategies and strategies for achieving village development (economic, agricultural, education, health, infrastructure, governance and spirituality). The inhibiting factor for human resources is still low because the majority of the population in the village of Massamaturu are farmers.

Keywords: Village Law, Development, Poverty

(c) () () Ini adalah artikel dengan akses terbuka dibawah licenci CC BY-NC-4.0
(https://creativecommons.org/licenses/by-nc/4.0/ ).

\section{PENDAHULUAN}

Undang-Undang Nomor 6 Tahun 2014 tentang Desa (selanjutnya disebut dengan Undang-Undang Desa), menjadikan desa sebagai satu kesatuan antara pemerintahan desa dan masyarakat desa. Pemerintahan desa yang dikepalai oleh kepala desa dipilih oleh masyarakat desa, sehingga pemerintahan desa bersumber pada masyarakat desa. UndangUndang Desa disambut sebagai payung hukum untuk desa yang mandiri, sejahtera dan demokratis. Dalam perwujudannya dapat dilihat pemerintah bertindak selaku pembimbing dan pengayom masyarakat, sedangkan masyarakat berperan selaku agen-agen pembangunan desa yang berpartisipasi aktif dalam penyelenggaraan pembangunan desa.

Pemerintah melaksanakan pembangunan Desa sebagai upaya dalam mensejahterakan rakyat. Pemerintah telah menetapkan Dana Desa yang bersumber dari Anggaran Pendapatan Belanja Negara sebesar 10 persen dari dana daerah. Dana yang didapatkan oleh Desa dialokasikan dalam kewenangan Desa. Pelaksanaan pembangunan Desa merupakan satu dari kewenangan Desa. Kewenangan Desa meliputi; penyelenggaraan pemerintahan Desa, pelaksanaan pembangunan Desa, pemberdayaan masyarakat Desa dan pembinaan masyarakat Desa. Dalam pelaksanaan pembangunan Desa pada hakikatnya merupakan proses perubahan yang harus terus menerus menuju ke arah yang lebih baik. Tujuan pembangunan Desa sesuai Pasal 78 UU Desa adalah meningkatkan kesejahteraan masyarakat Desa dan kualitas hidup manusia serta penanggulangan kemiskinan melalui pemenuhan kebutuhan dasar, pembangunan sarana dan prasarana Desa, pengembangan potensi ekonomi lokal, serta pemanfaatan sumber daya alam dan lingkungan secara berkelanjutan.

Dalam pelaksanaannya, tidak semua Desa mampu untuk mengimplementasikan UU Desa dalam pelaksanaan Pembangunan Desa dengan baik, termasuk Desa Massamaturu Kec. Polongbangkeng Utara Kab. Takalar yang sementara berupaya mengimplementasikan UU Desa dalam pelaksanaan Pembangunan Desa. Desa Massamaturu Kec. Polongbangkeng Utara Kab. Takalar merupakan satu dari 74. 754 Desa yang ada di Indonesia. Tercatat hingga akhir 2018 Desa Massamaturu Kec. Polongbangkeng Utara Kab. Takalar memiliki banyak potensi ekonomi dibidang pertanian, pekebunan dan pertenakan. Masyarakat Desa Massamaturu Kec. Polongbangkeng Utara Kab. Takalar berprofesi sebagai PNS, TNI, Wiraswasta, Pegawai BUMN, Peternak, petani, pedagang, tukang batu, supir, dan buruh. 
Desa Massamaturu Kec. Polongbangkeng Utara Kab. Takalar merupakan salah satu Desa yang mengimplementasikan UU Desa dalam pelaksanaan pembangunan desa. Dalam pelaksanaan UU Desa muncul keraguan dari pemerintah kepada kemampuan Pemerintah Desa dalam mengambil kebijakan dalam mengelola potensi dan pembangunan agar nantinya pembangunan tersebut bersifat nyata dan bijaksana, serta dengan adanya dana APBD desa tidak membuat Kepala Desa selaku Pemerintah Desa justru berhadapan dengan aparat penegak hukum. Untuk itu Kepala Desa dan Aparatur Desa yang lain perlu untuk membuat pembukuan yang akuntabel dan transparan. Permasalahan selanjutnya apakah rancangan program pembangunan akan terwujud sesuai dengan ketentuan yang berlaku dan diiringi dengan adanya biaya berupa kucuran dana dari APBN. Kemudian, apakah Desa mampu mengelola Dana Desa sesuai dengan kebutuhan dan Sumber Daya Manusia (SDM) yang ada.

Desa Massamaturu merupakan Desa yang masih dalam tahap pembangunan yang tidak lepas dari berbagai kendala. Pembangunan masyarakat desa pada hakekatnya bertujuan meningkatkan taraf hidup masyarakat secara keseluruhan agar lebih baik, lebih menyenangkan dan mengenakkan warga masyarakat dari keadaan sebelumnya. Mencapai kesejahteraan, itulah yang menjadi tujuannya. Pembangunan masyarakat desa dan tujuannya selalu dikaitkan dengan masalah "kemiskinan", yang dialami oleh sebagian "masyarakat" dalam kategori "masyarakat desa", dan lebih khusus lagi "masyarakat petani kecil."Hambatan dalam pelaksanaan "pembangunan masyarakat desa" di negara-negara Dunia Ketiga, antara lain adalah keadaan penduduk yang sangat "miskin", kebodohan dan pengalaman-pengalaman mereka yang serba menyusahkan dan menyedihkan di masa lampau, menyebabkan para petani dan buruh kasar pada umumnya dicekam rasa takut, menjadi apatis, berserah diri pada nasib (yang jelek), tidak ada keberanian untuk mencapai prestasi secara individu, tidak ada keberanian menanggung resiko untuk merubah nasib mereka yang bagaikan berada di dalam rawarawa yang memerlukan pertolongan dari luar untuk menariknya.

Salah satu prasyarat keberhasilan pengentasan kemiskinan adalah dengan cara mengidentifikasi kelompok sasaran dan wilayah sasaran dengan tepat. Program pengentasan dan pemulihan nasib orang miskin dan dimana dia berada. Aspek dimana "si miskin" dapat ditelusuri melalui si miskin itu sendiri serta melalu pendekatan-pendekatan profil wilayah atau karakter geografis.

Desa Massamaturu salasatu desa Desa yang berada di Kecamatan Polongbangkeng Utara Kabupaten Takalar dengan jumlah penduduk sekitar 1.771 jiwa atau 557 Kepala Keluarga. Terdiri dari empat dusun, yaitu dusun Bonto Rannu I dengan jumlah 193 kepala keluarga terdiri dari 309 laki-laki dan 298 perempuan, Bonto Rannu II dengan jumlah 135 kepala keluarga terdiri dari 203 laki-laki dan 214 perempuan, Bulubumbung I dengan jumlah 94 kepala keluarga terdiri dari 147 laki-laki dan 162 perempuan, Bulubumbung II dengan jumlah 131 kepala keluarga terdiri dari 215 laki-laki dan 223 perempuan dengan tingkat kemiskinannya mencapai 531 jiwa atau $30 \%$ dan 1.240 jiwa atau $70 \%$ masyarakat tergolong sejahtera (Data Desa Massamaturu 2018).

Melihat jumlah dan persentase diatas yang menggambarkan masih adanya masyrakat miskin yang berada di pedesaan seharusnya menjadi prioritas pembanguna diarahkan dengan maksimal. Selain kuantitas angka kemiskinan dan keluarga pra sejahtera masih ada di pedesaan, juga karena didesa kaya dengan sumberdaya alam yang belum digarap dengan maksimal, dengan begitu pengangguran yang memicu angka kemiskinan dapat ditekan, sehingga dapat menigkatkan pendapatan ekonomi keluarga, sert mengentaskan dari keluarga pra sejahtera menjadi keluarga sejahtera.

Pembangunan pedesaan pun harus dilakukan agar tidak ada ketimpangan pembangunan antara pembangunan pedesaan dan perkotaan. Dalam pembangunan pedesaan harus ada kerangka yang jelas apa yang akan dilaksanakan dalam jangka waktu tertentu serta adanya kesamaan gerak dan langkah pemerintah diberbagai tingkatan, dalam artian lain adanya kesamaan gerak dan langkah pembangunan perkotaan dan pedesaan (Sonntag et al, 2005).

Agar tercapainya pelaksanaan program pembangunan tersebut, hal yang paling dibutuhkan adalah kesadaran dan partisipasi aktif dari seluruh masyarakat agar pelaksanaan program pembangunan berjalan dengan baik. Selain partisipasi aktif dari masyarakat ternyata peran pemerintah juga diperlukan untuk mengarahkan, membimbing, mengawasi, dan memberikan anggaran sebagai bentuk 
kepedulian pemerintah terhadap pembangunan pedesaan. Sebagai Negara yang merdeka dan berdaulat, Indonesia berhak menentukan nasib bangsanya sendiri, hal ini diwujudkan dalam bentuk pembangunan. Menurut Sondang P.Siagian (1999), pembangunan merupakan suatu usaha atau rangkaian pertumbuhan dan perubahan yang terencana yang dilakukan secara sadar oleh suatu bangsa, Negara dan pemerintah menuju pada modernitas dalam rangka pembinaan bangsa. Sedangkan menurut Bintoro (1988) bahwa pembangunan dapat diartikan pula sebagai suatu proses pembaharuan yang kontinyu dan terus menerus dari suatu keadaan yang dianggap lebih baik.

Pembangunan yang dilaksanakan didaerah ditujukan untuk meningkatkan kesejahteraan masyarakat dan taraf hidup masyarakat. Hal ini sesuai dengan tujuan Negara Indonesia, sebagaimana di amanatkan dalam Pembukaan Undang- Undang 1945, yaitu melindungi segenap bangsa Indonesia dan seluruh tumpah darah Indonesia, memajukan kesejahteraan umum, mencerdaskan kehidupan bangsa dan ikut melaksanakan ketertiban dunia yang berdasarkan kemerdekaan, perdamaian abadi, dan keadilan sosial. Kesejahteraan umum/ rakyat dapat di tingkatkan kalau kemiskinan dapat dikurangi, sehingga untuk meningkatkan kesejahteraan masyarakat/ umum dapat dilakukan melalui upaya penanggulangan kemiskinan.

Ada tiga yang menyebabkan kemiskinan bisa terjadi, yakni kemiskinan (nature) alamiah adalah kemiskinan yang disebabkan oleh faktor alam seperti gempa bumi, tsunami, banjir dan sebagaianya yang kemudian menimbulkan kemiskinan bagi warga setempat, kedua kemiskinan (cultural) budaya adalah kemiskinan yang diakibatkan oleh budaya masyarakat setempat seperti malas bekerja, boros, percaya terhadap hari keberuntungan dan sebagainya yang menyebabkan mereka miskin, dan ketiga kemiskinan (structural) struktur adalah kemiskinan yang disebabkan oleh sistem yang ada dalam masyrakat dimana struktur bermain dalam menimbulkan kemiskinan seperti eksploitasi, dan kebijakan pemerintah yang tidak adil.

Upaya penangulangan kemiskinan yang dimulai sejak pelita 1 sudah menjangkau seluruh pelosok tanah air dan telah menghasilkan perkembangan yang positif. Namun demikian, krisis moneter dan ekonomi yang melanda
Indonesia sejak tahun 1997 telah mengecilkan arti berbagai pencapaian pembangunan tersebut.

Ada beberapa kelemahan upaya penanggulangan kemiskinan yang berjalan selama ini antara lain program- program penanggulangan kemiskinan masih bersifat parsial, belum terpadu dan komprehensif yaitu belum tersedianya instrument upaya penanagulangan kemiskinan yang spesifik sesuai dengan keragaman dimensi permasalahan kemiskinan disetiap daerah dan kebijakan yang semula di proyeksikan untuk mengatasi masalah kemiskinan pada kenyataannya melahirkan masalah baru, yang menyebabkan berkurangnya kepercayaan publik terhadap pemerintah dalam menangani masalah kemiskinan.

Kemiskinan masih terlihat dimanamana, jelas kita belum berhasil mewujudkan sila tersebut. Ada empat aspek utama mengapa usaha penanggulangan kemiskinan menjadi penting bagi daerah maupun secara nasional, yaitu : Aspek kemanusian, aspek ekonomi, aspek Sosial dan politik dan aspek keamanan.

\section{TINJAUAN PUSTAKA}

\section{A. Teori Partisipasi Masyarakat}

Dalam kamus bahasa Indonesia, partisipasi adalah keikut sertaan seseorang dalam suatu kegiatan atau turut berperan atau peran serta. Menurut Dr. Made Pidarta, partisipasi adalah keterlibatan seseorang atau beberapa orang dalam suatu kegiatan. Keterlibatan dapat berupa keterlibatan mental dan emosi serta fisik dalam menggunakan segala kemampuan yang dimilikinya( berinisiatif) dalam segala kegiatan yang dilaksanakan serta mendukung pencapaian tujuan dan tanggung jawab atas segala keterlibatan.

Partisipasi merupakan keterlibatan mental dan emosi dari seseorang didalam situasi kelompok yang mendorong mereka untuk menyokong kepada pencapaian tujuan pada tujuan kelompok tersebut dan ikut bertanggung jawab terhadap kelompoknya. (Siti Irene, 2011:50)

Dalam Peraturan Menteri Dalam Negeri Nomor 5 Tahun 2007 menyebutkan bahwa partisipasi adalah keikutsertaan dan keterlibatan masyarakat secara aktif dalam proses perencanaan pembangunan.

Partisipasi adalah penentuan sikap dan keterlibatan hasrat setiap individu dalam situasi dan kondisi organisasinya, sehingga pada 
akhirnya mendorong individu tersebut untuk berperan serta dalam pencapaian tujuan organisasi, serta ambil bagian dalam setiap pertanggungjawaban bersama. (Inu Kencana, 2002:132). Partisipasi masyarakat atau partisipasi warga adalah proses ketika warga, sebagai makhluk individu maupun kelompok sosial dan organisasi, mengambil peran serta ikut mempengaruhi proses perencanaan pelaksanaan dan pemantauan kebijakan yang langsung mempengaruhikehidupan mereka. (Sumarto, 2003:17)

Menurut pasaribu dan simajuntak, partisipasi masyarakat berarti masyarakat ikut serta , yaitu mengikuti dan menyertai pemerintah karena kenyataannya pemerintahlah yang sampai dewasa ini merupakan perancang, penyelenggara, dan pembayar utama dalam pembangunan. Masyarakat diharapkan dapat ikut serta, karena diselenggarakan dan dibiayai utama oleh pemerintah itu dimaksudkan untuk sebesar-besarnya kesejahteraan masyarakat sendiri, untuk rakyat banyak. (dalam Siti Fatimah, 2012:10)

Gaventa dan Valderma mengidentifikasi tiga tradisi konsep partisipasi bila dikaitkan dengan praktis pembangunan masyarakat yang demokratis, yaitu partisipasi politik, pasrtisipasi sosial, dan partisipasi warga.

a. Partisipasi Politik

Partisipasi politik sering kali dihubungkan dengan proses politik yang demokratik, yang melibatkan interaksi perseorangan dan organisasi. Partisipasi politik dihubungkan dengan demokrasi politik yang mengedepankan prinsip perwakilan dan partisipasi tidak langsung.

\section{b. Partisipasi Sosial}

Partisipasi sosial berorientasi pada perencanaan dan implementasi pembangunan. Partisipasi ini ditempatkan sebagai keterlibatan masyarakat terutama yang terkait dengan proses pembangunan dalam konsultasi data dan pengambilan keputusan pada semua tahapan siklus proyek pembangunan, dari evaluasi sampai penilaian, implementasi, pemantauan, dan evaluasi.

\section{B. Pengertian Kemiskinan}

Kemiskinan adalah suatu kondisi ketidakmampuan secara ekonomi untuk memenuhi standar hidup rata-rata masyarakat di suatu daerah.kondisi ketidakmampan ini ditandai dengan rendahnya kemampuan pendapatan untuk memenuhi kebutuhan pokok baik berupa pangan,sandang,pangan maupun mapan. Kemampuan pendapatan yang rendah ini juga akan berdampak berkurangnya kemampuan untuk memenuhi standar hidup rata-rata seperti kesehatan masyarakat dan standar pendidikan.

Kondisi masyarakat yang di sebut miskin dapat diketahui berdasarkan kemampuan pendapatan dalam memenuhi standar hidup (Nugroho, 1995). Pada prinsipnya, standar hidup di suatu masyarakat tidak sekedar tercukupinya kebutuhan atau pangan, akan tetapi juga tercukupinya kebutuhan akan kesehatan maupun pendidikan. Tempat tinggal ataupun pemukiman yang layak merupakan salah satu dari standar hidup kesejateraan masyarakat disuatu daerah. Berdasarkan kondisi ini, suatu masyarakat disebut miskin apabila memiliki pendapatan jauh lebih rendah dari rata-rata pendapatan sehingga tidak banyak memiliki kesepatan untuk mensejahterakan dirinya (Suryawati, 2004) .

Pengertian kemiskinan yang saat ini populer dijadikan studi pembangunan adalah kemiskinan yang seringkali dijumpai di negaranegara berkembang dan negara-negara dunia ketiga. Persoalan kemiskinan masyarakat di negara-negara ini hanya sekedar bentuk ketidakmampuan pendapatan, akan tetapi telah meluas pada bentuk ketidakberdayaan secara sosial maupun politik (Suryawati, 2004). Kemiskinan juga dianggap sebagai bentuk permasalahan pembangunan yang diakibatkan adanya dampak negatif dari pertumbuhan ekonomi yang tidak seimbang sehingga memperlebar kesenjangan pendapatan antar masyarakat maupun kesenjangan pendapatan antar daerah (inter region income gap) (harahap, 2006). Studi pembangunan saat ini tidak hanya memfokuskan kajiannya pada faktor faktor yang menyebabkan kemiskinan, akan tetapi juga mulai mengidentifikasika segala aspek yang dapat menjadikan miskin. Secara umum, kemiskinan diartikan sebagai kondisi ketidakmampuan pendapatan dalam mencukupi kebutuhan pokok sehingga kurang mampu untuk menjamin kelangsungan hidup (Suryawati, 2004 : 122). Kemampuan pendapatan untuk mencukupi kebutuhan pokok berdasarkan standar harga tentu adalah rendah sehingga kurang menjamin terpenuhinya standar kualitas pada umumnya. Berdasarkan pengertian ini, maka kemiskina secara umum didefinisikan sebagai suatu kondisi ketidakmampuan pendapatan dalam memenuhi kebutuhan pokok dan kebutuhan lainnya yang dapat menjamin terpenuhinya standar kualitas hidup. 
Kotze (dalam Hikmat, 2004:6) menyatakan bahwa masyarakat miskin memiliki kemampuan yang relatif baik untuk memperoleh sumber melalui kesempatan yang ada. Kendatipun bantuan luar kadang-kadang digunakan, tetapi tidak begitu saja dapat dipastikan sehingga masyarakat bergantung pada dukungan dari luar. Pendekatan pemberdayaan ini dianggap tidak berhasil karena tidak ada masyarkat yang dapat hidup dan berkembang bila terisolasi dari kelompok masyarakat lainnya. Pengisolasian ini menimbulkan sikap pasif bahkan keadaan menjadi semakin miskin.

Tidak sedikit penjelasan mengenai sebab sebab kemiskinan. Kemiskinan massal yang terjadi di banyak negara yang baru saja merdeka setelah perang Dunia II memfokuskan pada keterbelakangan dari perekonomian negara tersebut akar masalahnya (Hardiman dan Midgley, dalam Kuncoro,1997: 131).

Penduduk negara terebut miskin menurut Kuncoro (1997: 131) karenan menggantungkan diri pada sektor pertanian yang subsistem, metode produksi yang tradisional, yang seringkali dibarengi dengan sikap kapasitis terhadap lingkungan

Sharp, et.al (dalam Kuncoro, 1997: 131) mencoba mengidentifkasi penyebab kemiskinan dipandang dairi sisi ekonomi. Pertama, secara mikro, kemiskinan muncul karena adanya ketidaksamaan pola kepemilikan sumber daya yang menimbulkan distribusi pendapatan yang timpang. Penduduk miskin hanya memiliki sumber daya dalam jumlah terbatas dan kualitasnya rendah.kedua,kemiskinan muncul akibat perbedaan dalam kualitas sumber daya manusia. Kualitas sumber daya manusia yang rendah berarti produktivitasnya rendah, yang pada gilirannya upahnya rendah. Rendahnya kualitas sumber daya manusia ini karena rendahnya pendidikan, nasib yang kurang beruntung, adanya diskirminasi, atau karena keturunan, ketiga, kemiskinan muncul akibat perbedaan akses dalam modal.

\section{Teori Pembangunan Bottom Up}

Dilihat dari proses dan mekanisme perumusan program pembangunan masyarakat, pendekatan pemberdayaan cenderung mengutamakan alur dari bawah keatas. Dalam hal ini perumusan program yang akan dilaksanakan di tentukan oleh identifikasi masalah dsn kebutuhan dari dan oleh masyarakat sendiri. Sehubungan dengan hal ini proses dan mekanisme perumusan program pembangunan masyarakat dapat melalui dua kemungkinan. Yang pertama, identifikasi masalah dan kebutuhan dari masyarakat tersebut kemudian direspon oleh masyarakat yang bersangkutan dalam bentuk program pembangunan yang direncanakan dan dilaksanakan oleh masyarakat sendiri. Dengan demikian melalui mekanisme jenis yang pertama ini dapat dikatakan bahwa proses pembangunan masyarakat berasal dari, oleh dan untuk masyarakat. Dilihat dari pemikiran yang menempatkan masyarakat sebagai subyek pembangunan, sebetulnya model ini yang paling ideal karena menggambarkan kapasitas masyarakat dalam mengelolah masa depannya. Model ini juga terjadi melalui proses belajar sambil menyesuaikan dengan dinamika kehidupan dan lingkungan yang berkembang. Dengan demikian proses ini sudah lebih teruji. Disamping itu, melalui proses ini terbentuk pola tindakan bersama yang melembaga (institution) dan masyarakat juga dapat memperoleh pengetahuan serta kearifan local. Yang kedua, identifikasi masalah dan kebutuhan dari bawah ini kemudian di akomodasi oleh pemerintah baik daerah maupun pusat, dalam hal ini dinas dinas terkait, untuk dimasukkan sebagai mata program dalam perencanaan pembangunan. Bentuk kedua inilah yang kemudian dikenal dengan proses dan mekanisme pembangunan yang bersiifat bottom -up.

\section{Teori Kesejahteraan.}

1. Ide Tentang Kesejahteraan Sosial.

Ide tentang kesejahteraan sosial didasarkan atas asumsi bahwa masyarakat manusia dapat di organisasi dan diatur untuk menghasilkan dan memberikan hal - hal ini, dan dapat melakukannya, masyarakat mempunyai kewajiban moral untuk mewujutkannya dengan berhasil.

Pengertian kesejahteraan sosial sebagai suatu gambaran tentang masyarakat juga terdapat dalam Undang-Undang Republik Indonesia No. 6 tahun 1974 tentang KetentuanKetentuan Pokok Kesejahteraan sosial. Pasal 2 ayat 1. Undang-undang ini menyatakan:

Kesejahteraan sosial ialah suatu tata kehidupan dan penghidupan sosial materiil maupun spritual yang diliputi oleh rasa keselamatan, kesusilaan dan ketentraman lahir batin, yang memungkinkan bagi setiap warga 
negara untuk mengadakan usaha pemenuhan kebutuha kebutuhan jasmaniah, rohaniah dan sosial yang sebaik-baiknya bagi diri, keluarga serta masyarakat dengan menjunjung tinggi hakhak asasi serta kewajiban manusia sesuai dengan pancasila.

Inti dari pengertian kesejahteraan sosial dalam undang-undang ini adalah suatu tata kehidupan dan penghidupan sosial materiilataupun spritual, yaitu suatu tata bagaimana orang hidup dan bagaimana menghidupi diri dan keluarganya, yang berarti suatu keteraturan, atau memberi gambaran tentang masyarakat Indonesia. Di dalam tata atau keteraturan tersebut dimungkinkan setiap warga negara untuk melakukan usaha-usah untuk meningkatkan kesejahteraan bagi diri dan keluarganya.

Menurut definisi tersebut, kesejateraan sosial merupakan suatu tata yang berarti keteraturan atau order yang bukan merupakan ciri individu atau perorangan, melainkan ciri masyarakat sebagai suatu kesatuan atau secara keseluruhan, yaitu masyarakat indonesia. Dengan demikian bagi setiap orang yang ada di indonesia, di wilayah manapun ia berada dinaungi oleh tata kehidupan dan penghidupan sosial materiil ataupun spiritual yang sama, apapun atau bagaimanapun kondisi tata kehidupan dan penghidupan tersebut. Dalam istilah penelitian, kesejahteraan sosial semacam ini merupakan konstanta, bukan variabel.

Menurut Walter A. Friedlander (1961) kesejahteraan sosial adalah sistem yang terorganisir dari pelayanan-pelayanan sosial dan lembaga-lembaga yang bertujuan untuk membantu individu dan kelompok untuk mencapai standar hidup dan kesehatan yang memuaskan dan relasi-relasi pribadi dan sosial yang memungkinkan mereka mengembangkan kemampuannya sepenuh mungkin dan meningkatkan kesejahteraannya secara selaras dengan kebutuhan keluarga dan masyarakat.

$$
\text { Lalu menurut Zastrow (2000) }
$$

kesejahteraan sosial adalah sebuah sistem yang meliputi program dan pelayanan yang membantu orang agar dapat memenuhi kebutuhan sosial, ekonomi, pendidikan dan kesehatan yang sangat mendasar untuk memelihara masyarakat. Sebagaimana batasan PBB, kesejahteraan sosial adalah kegiatankegiatan yang terorganisasi yang betujuan untuk membantu individu atau masyarakat guna memenuhi kebutuhan-kebutuhan dasarnya dan meningkatkan kesejahteraan selaras dengan kepentingan keluarga dan masyarakat.

\section{E. Undang - Undang Desa}

Undang-undang nomor 6 tahun 2014 tentang desa (selanjutnya disebut undang-undang desa) disahkan oleh Presiden Susilo Bambang Yudhoyono pada tanggal 15 Januari 2014. Pengesahan undangundang tersebut menggantikan Peraturan Pemerintah (PP) nomor 72 tahun 2005 tentang desa.

Desa memiliki hak asal usul dan hak tradisional dalam mengatur dan mengurus kepentingan masyarakat setempat dan berperan mewujudkan cita-cita kemerdekaan berdasarkan Undang-Undang Dasar Negara Republik Indonesia Tahun 1945. Dalam perjalanan ketatanegaraan Republik Indonesia, Desa telah berkembang dalam berbagai bentuk sehingga perlu dilindungi dan diberdayakan agar menjadi kuat, maju, mandiri, dan demokratis sehingga dapat menciptakan landasan yang kuat dalam melaksanakan pemerintahan dan pembangunan menuju masyarakat yang adil, makmur, dan sejahtera. Desa dalam susunan dan tata cara penyelenggaraan pemerintahan dan pembangunan perlu diatur tersendiri dengan undang-undang. Terkhus pokok permasalahan yang dikaji adalah pasal 78 ayat 1 undangundang nomor 06 tahun 2014 pada yang berbunyi " Pembangunan desa bertujuan meningkatkan kesejahteraan masyarakat desa dan kualitas hidup manusia serta penanggulangan kemiskinan melalui pemenuhan kebutuhan dasar, pembangunan sarana dan prasarana desa, pengembangan potensi ekonomi local, serta pemanfaatan sumber daya alam dan lingkungan secara berkelanjutan.

\section{METODE PENELITIAN}

Jenis Penelitian ini merupakan penelitian Kualitatif. Penelitian ini termasuk penelitian deskriptif kualitatif. Karena pendekatan kualitatif memiliki prosedur penelitian yang menghasilkan data deskriptif berupa kata-kata orang-orang yang diwawancarai.

Penelitian ini dilaksanakan di Desa Massamaturu Kecamatan Polongbangkeng Utara Kabupaten Takalar. Penduduknya memiliki berbagai sumber mata pencaharian bertani, berkebun, beternak, karyawan, PNS, TNI dan 
POLRI serta ada pula yang bekerja serabotan. Program yang sedang dikembangkan yaitu menjadi desa ekowisata atau DESWITA ( desa wisata).

Dalam penelitian ini teknik yang di pakai dalam mengumpulkan data adalah teknik observasi, wawancara dan dokumentasi. Ketiga teknik tersebut dijelaskan sebagai berikut.

\section{a. Obesrvasi}

Merupakan teknik pengumpulan data, dimana peneliti melakukan pengamatan secara langsung ke objek penelitian untuk melihat dari dekat kegiatan yang dilakukan hal ini untuk menghindari kalau suatu data yang dicari merupakan data masih dirahasiakan. Adapun hal yang di observasi oleh peneliti di antaranya data yang terkait dengan program pemerintah desa dalam menanggulangi kemiskinan dan manfaat program-program tersebut.

\section{b. Wawancara}

Penelitian ini dalam melakukan pengumpulan data menggunakan teknik wawancara semiterstruktur agar lebih bebas dan menemukan permasalahan secara lebih terbuka yang dilakukan dengan pemerintah desa dan masyarakat.

\section{c. Dokumentasi}

Dokumen digunakan oleh peneliti untuk melengkapi dalam pengumpulan data. Dokumen yang akan dikumpulkan peneliti adalah program kerja desa dan realisasi pembangunan desa massamaturu.

\section{HASIL DAN PEMBAHASAN}

Berdasarkan hasil penelitian yang telah diuraikan, maka pada pembahasan hasil penelitian untuk mengetahui lebih lanjut tentang pembangunan di desa Massamaturu sebagai realisasi UU No.6 Tahun 2014 dalam penanggulangan kemiskinan.

\section{Pola pembangunan di desa Massamaturu sebagai realisasi UU No.6 Tahun 2014 dalam penanggulangan kemiskinan}

Salah satu proses atau rencana perencanaan yang sering dilakukan dalam melakukan rencana pembangunan adalah dengan menggunakan sistem pembangunan yang bersifat Button Up. Button Up Planning adalah perencanaan yang dibuat berdasarkan kebutuhan, keinginan dan permasalahan yang dihadapi oleh bawahan bersama-sama dengan atasan menetapkan kebijakan atau pengambilan keputusan dan atasan juga berfungsi sebagai fasilitator. Sedangkan dalam pengertian dibidang pemerintahan, button up planning atau perencanaan bawah adalah perencanaan yang disusun berdasarkan kebutuhan mereka sendiri dan pemerintah hanya sebagai fasilitator.

Polah Dari bawah ke atas (bottom-up) merupakam pendekatan dalam upaya melibatkan semua pihak sejak awal, sehingga setiap keputusan yang diambil dalam perencanaan adalah keputusan mereka bersama, dan mendorong keterlibatan dan komitmen sepenuhnya untuk melaksanakannya. Kelemahannya memerlukan banyak waktu dan tenaga untuk perencanaan. Diperlukan pengembangan budaya perusahaan yang sesuai.

Perjalanan ketatanegaraan Republik Indonesia, Desa telah berkembang dalam berbagai bentuk sehingga perlu dilindungi dan diberdayakan agar menjadi kuat, maju, mandiri, dan demokratis sehingga dapat menciptakan landasan yang kuat dalam melaksanakan pemerintahan dan pembangunan menuju masyarakat yang adil, makmur, dan sejahtera. Desa dalam susunan dan tata cara penyelenggaraan pemerintahan dan pembangunan perlu diatur tersendiri dengan undang-undang. Terkhus pokok permasalahan yang dikaji adalah pasal 78 ayat 1 undangundang nomor 06 tahun 2014 pada yang berbunyi " Pembangunan desa bertujuan meningkatkan kesejahteraan masyarakat desa dan kualitas hidup manusia serta penanggulangan kemiskinan melalui pemenuhan kebutuhan dasar, pembangunan sarana dan prasarana desa, pengembangan potensi ekonomi local, serta pemanfaatan sumber daya alam dan lingkungan secara berkelanjutan.

Pendekatan

perencanaan pembangunan Buttom-Up Planning adalah perencanaan yang dibuat berdasarkan kebutuhan, keinginan dan permasalahan yang dihadapi oleh bawahan bersama-sama dengan atasan menetapkan kebijakan atau pengambilan keputusan dan atasan juga berfungsi sebagai fasilitator. Sedangkan dalam pengertian dibidang pemerintahan, bottom-up planning atau perencanaan bawah adalah perencanaan yang disusun berdasarkan kebutuhan mereka sendiri dan pemerintah hanya sebagai fasilitator. Salah 
satu pola pendekatan perencanaan pembangunan yang kini sedang dikembangkan adalah perencanaan pembangunan partisipatif.

Pemerintah desa Massamaturu sejak tahun 2015 telah mencoba melakukan perencanaan pembangunan partisipatif didalam kerangka menggali aspirasi yang berkembang di masyarakat melalui musyawarah tingkat RT, RW, desa , kecamatan dan kabupaten. Sebuah langkah positif yang patut dikembangkan lebih lanjut, apalagi hal seperti itu masih dalam taraf pembelajaran yang tentu saja disana-sini masih terdapat kelemahan baik dalam tataran konsep maupun implementasinya di masyarakat.

Perencanaan pembangunan partisipatif merupakan pola pendekatan perencanaan pembangunan yang melibatkan peran serta masyarakat pada umumnya bukan saja sebagai obyek tetapi sekaligus sebagai subyek pembangunan, sehingga nuansa yang dikembangkan dalam perencanaan pembangunan benar-benar dari bawah (bottomup approach). Nampaknya mudah dan indah kedengarannya, tetapi jelas tidak mudah implementasinya karena banyak faktor yang perlu dipertimbangkan, termasuk bagaimana sosialisasi konsep itu di tengah-tengah masyarakat.

Meskipun demikian, perencanaan pembangunan yang melibatkan semua unsur/komponen yang ada dalam masyarakat tanpa membeda-bedakan ras, golongan, agama, status sosial, pendidikan, tersebut paling tidak merupakan langkah positif yang patut untuk dicermati dan dikembangkan secara berkesinambungan baik dalam tataran wacana pemikiran maupun dalam tataran implementasinya di tengah-tengah masyarakat. Sekaligus, pendekatan baru dalam perencanaan pembangunan ini yang membedakan dengan pola-pola pendekatan perencanaan pembangunan sebelumnya yang cenderung sentralistik.

Era otonomi daerah yang tengah dikembangkan di tengah-tengah masyarakat dengan asas desentralisasi ini diharapkan kesejahteraan masyarakat dalam pengertian yang luas menjadi semakin baik dan meningkat. Lagipula, pola pendekatan perencanaan pembangunan ini sekaligus menjadi wahana pembelajaran demokrasi yang sangat baik bagi masyarakat. Hal ini tercermin bagaimana masyarakat secara menyeluruh mampu melakukan proses demokratisasi yang baik melalui forum-forum musyawarah yang melibatkan semua unsur warga masyarakat mulai dari level RT (Rukun Tetangga), RW (Rukun Warga), Desa, Kecamatan, sampai Kabupaten.

\section{Pelaksanaan UU No.6 Tahun 2014 pasal 78 ayat (1) berdampak dalam penaggulangan kemiskinan di desa Massamaturu}

Penanggulangan kemiskinan di pemerintah desa Massamaturu dalam mengambil kebijakan dan program yang di terapkan benar-benar harus menjangkau dan mendampingi penduduk miskin. Penduduk miskin adalah orang-orang yang memiliki namun serba terbatas dan kepercayaan diri penduduk miskin merupakan titik masuk utama dari seluruh rangkaian membantu mereka keluar dari kemiskinan. Kelompok afinitas penduduk miskin merupakan instrumen yang amat efektif bagi penduduk miskin untuk mampu keluar dari kemiskinan.

Kemiskinan diartikan sebagai kondisi ketidakmampuan pendapatan dalam mencukupi kebutuhan pokok sehingga kurang mampu untuk menjamin kelangsungan hidup (Suryawati, 2004 : 122). Kemampuan pendapatan untuk mencukupi kebutuhan pokok berdasarkan standar harga tentu adalah rendah sehingga kurang menjamin terpenuhinya standar kualitas pada umumnya. Berdasarkan pengertian ini, maka kemiskinan secara umum didefinisikan sebagai suatu kondisi ketidakmampuan pendapatan dalam memenuhi kebutuhan pokok dan kebutuhan lainnya yang dapat menjamin terpenuhinya standar kualitas hidup.

Berdasarkan undang undang No.24 Tahun 2004 kemiskinan adalah kondisi sosial ekonomi seseorang atau sekelompok orang yang tidak memenuhi hak-hak dasarnya untuk mempertahankan dan mengembangkan kehidupan yang bermartabat. Kebutuhan dasar yang menjadi hak seseorang atau sekelompok orang meliputi kebutuhan pangan, kesehatan, pendidikan,pekerjaan, perumahan, air bersih, pertanahan, sumber daya alam, lingkungan hidup, rasa aman dari perlakuan atau ancaman tindak kekerasan, dan hak untuk berpartisipasi dalam penyelenggaraan kehidupan sosial dan politik. Laporan Bidang (Kesra) tahun 2004 menerangkan pula bahwa kondisi yang disebut miskin ini juga berlaku pada mereka yang bekerja akan tetapi pendapatnya tidak 
mencukupi untuk memenuhi kebutuhan pokok/ dasar.

Pemerintah desa Massamaturu dalam Bidang ekonomi memberikan program-program yang dapat meminimalisir terjadinya kemiskinan di desa dengan upaya-upaya sebagai berikut:

a. Mengupayakan agar hasil produksi pertanian dan perkebunan tanaman pangan seperti padi, jagung dan palawija dapat meningkat dengan pemberian bantuan alat alat pertanian.

b. Mengupayakan agar hasil pengelolaan peternakan baik ternak kecil maupun ternak besar dapat meningkat dengan bantuan bibit dan penyuluhan.

c. Mengembangkan home industry dan usaha kecil menengah dengan memberdayakan kelompok tani dan badan usaha mlilik desa (BUMDES) dan memberikan bantuan modal usaha dan kredit bunga rendah.

d. Mengembangkan kemampuan pengelolaan pertanian dangan penyuluhan pertanian.

e. Pemenuhan kebutuhan saprodi bagi masyarakat petani miskin dengan memberikan bantuan modal usaha.

f. Menggeliatkan pendapatan masyarakat dengan perbaikan pasar desa.

g. Memperlancar transportasi perdagangan hasil pertanian masyarakat dengan perbaikan sarana dan prasarana inprastruktur desa.

3. Faktor penentu dalam penaggulangan kemiskinan di desa Massamaturu melalui pelaksanaan UU No.6 Tahun 2014 terkait pembangunan desa

Penentu dalam penaggulangan

kemiskinan di desa Massamaturu dilakukan dengan strategi dan program pembangunan desa yang di sesuaikan dengan visi dan misi pemerintahan desa secara baik.

Sementara itu Rondinelli, ( 1990:91) mengemukakan ada tiga strategi dasar program yang bertujuan untuk membantu penduduk miskin yakni:

a. Bantuan yang disalurkan ke tempat dimana mayoritas orang miskin hidup, melalui program pembangunan desa terpadu atau proyek produksi pelayanan yang berorientasi pada penduduk desa

b. Bantuan dipusatkan untuk mengatasi cacat standar kehidupan orang orang miskin melalui program kebutuhan dasar manusia.

c. Bantuan dipusatkan pada kelompok yang mempunyai ciri sosial ekonomi yang sama yang mendorong atau mempertahankam mereka untk terus berkubang di dalam lingkaan kemiskinan melalui royek yang dirancang bagi masyarakat tertentu.

\section{a. Arah Kebijakan Pembangunan Desa}

Kebijakan Umum Desa Massamaturu secara garis besar dapat ditempuh melalui 4 (empat) Program Pembangunan untuk Tahun 2016 - 2022. Program Pembangunan tersebut akan dapat dicapai melalui beberapa tahapan dalam pembangunan. Agar masing-masing tahapan dalam pembangunan dapat dilaksanakan secara efektif dan efisien, maka perlu didukung dengan kebijakan yang matang dan komprehensif. Oleh karena itu arah kebijakan dari masing-masing tahapan dalam pembangunan ditetapkan sebagai berikut :

1. Memperkuat kelembagaan desa
a) Optimalisasi
Kepengurusan
Kelembagaan Desa yang ada
b) Periode Kepengurusan Kelembagaan Desa yang ada
c) Penempatan Personil sesuai dengan keahliannya
d) Penjelasan Tugas Pokok dan Fungsi Kelembagaan Desa
e) Penyusunan Rencana Program Kerja Kelembagaan Desa

2. Menyelenggarakan Pemerintahan dan Melaksanakan Pembangunan yang Partisipatif, Tranparansi, Kondisional, Akuntabelitas, serta kesamaan Hak dan Kewajiban

3. Mewujudkan Desa Massamaturu yang aman, Tentram dan Damai
a) Menggalakkan Sistem Keamanan Lingkungan (Siskamling).
b) Penanggulangan kriminalitas dan gangguan keamanan dan ketertiban.
c) Peningkatan hasil-hasil sosial kemasyarakatan dan menjaga keharmonisan antar pribadi, antar kelompok dan antar dusun.
d) Penyelesaian permasalahan mengupayakan dengan sistem kekeluargaan.

4. Memberdayakan Masyarakat untuk Meningkatkan Kesejahteraan Masyarakat

a) Menggoptimalkan Badan Usaha Milik Desa berbentuk koperasi.

b) Mengupayakan penanaman modal usaha bagi golongan ekonomi lemah.

c) Mengembangkan jiwa usaha mandiri atau kewirausahaan.Penggalian potensi desa dibidang ekonomi yang 
masih terpendam / belum berkembang.

d) Menggalakkan gerakan gotongroyong demi untuk menumbuhkan kebersamaan, sehingga tercipta kerukunan antar masyarakat yang pada akhirnya tercipta masyarakat yang bersatu.

\section{b. Perencanaan Pembangunan Desa}

Perencanaan pembangunan Desa, pemerintah Desa melaksanakan tahapan yang meliputi:penyusunan RPJM Desa; dan penyusunan RKP Desa. Dalam Perencanaan Pembangunan Desa dibuat suatu rancangan pembangunan yang realistis dan capable.

Program Perencanaan Pembangunan Desa Massamaturu, dengan indikasi kegiatan sebagai berikut :

\section{Pengembangan partisipasi masyarakat dalam perumusan program dan krbijakan layanan publik.}

\section{Penyusunan dokumen RPJM-Desa}

3. Penyusunan Rancangan RKP-Desa 4. Penyelenggaraan Musrembang desa
RPJM-Desa \& RKP-Desa

Dalam hal perencanaan Desa Massamaturu yang menjadi tolak ukurnya adalah desa menentukan tujuan dari perencanaan pembangunan desa agar segala yang akan dicapai dapat dilakukan dengan maksimal. Oleh karena itu, maka disusunlah perencanaan-perencanaan pembangunan desa yang meliputi penyelenggaraan pemerintahan, pembangunan desa, pemberdayaan kemasyarakatan, dan pembinaan kemasyarakatan.Sehingga pelaksanaan pembangunan desa Massamaturu lebih terarah, terpadu, dan tepat sasran.

\section{c. Strategi Pembangunan Desa}

Untuk mewujudkan visi yang mendukung oleh misi, maka Pelaksanaan Pembangunan di Desa Massamaturu ditempuh dengan beberapa strategi pembangunan desa sebagai berikut :

1. Strategi Penguatan Kelembagaan Desa yang ada di Desa Massamaturu yang diarahkan agar semua yang terlibat dalam kelembagaan desa yang ada dapat menjalankan tugas pokok dan fungsinya sesuai dengan peraturan yang ada.

2. Stategi Pemberdayaan Masyarakat yang diarahkan untuk meningkatkan sumber daya manusia mempunyai kepedulian untuk memajukan desa dilihat dari faktor pendidikan, ekonomi dan sosial budaya.

3. Strategi Pembangunan Desa yang partisipatif yang diarahkan agar masyarakat benar-benar dapat berpartisipasi dalam setiap proses perencanaan sampai pelaksanaan pembangunan dan mampu mengevaluasi pelaksanaan pembangunan.

Strategi Pembangunan Pertama dimaksudkan untuk mempersiapkan sumber daya manusia di desa yang terlibat langsung dalam kepengurusan kelembagaan desa yang ada sebagai pelaku pembangunan di desa. Dengan kelembagaan desa yang kuat diharapkan dalam penyusunan rencana program kegiatan tidak asal-asalan akan tetapi berdasarkan pada pokok-pokok permasalahan yang dihadapi di desa dengan mempertimbangkan skala prioritas kebutuhan masyarakat.

Strategi Pembangunan kedua dimaksudkan bahwa penyelenggaraan pemerintahan dan pelaksanaan pembangunan di desa yang ditujukan untuk meningkatkan taraf hidup dan kesejahteraan masyarakat melalui penetapan kebijakan di bidang pendidikan, ekonomi, sosial dan budaya.

Strategi Pembangunan Ketiga dimaksudkan agar masyarakat baik perorangan maupun kelompok berpartisipasi dalam proses pengambilan kebijakan publik supaya kepentingan-kepentingannya (baik perorangan maupun kelompok) dapat diakomodasi dalam pengambilan kebijakan publik.

\section{d. Strategi pencapaian Pembangunan Desa}

Strategi pencapaian pembangunan desa massamaturu dalam rangka menjalankan misi untuk mewujudkan Visi desa di tempuh strategi pokok pembangunan desa massamaturu di arahkan untuk membangun aspek manusia, ekonomi, fisik, alami dan aspek sosial di dalam desa massamaturu terutama dalam hubungan pemulihan hak-hak dasar masyarakat dalam pelayanan pendidikan, kesehatan, pertanian, peternakan, sarana dan prasarana jalur perhubungan masyarakat.

Dari isu strategis setiap bidang yang dirumuskan untuk membantu mengedentifikasi tindakan tindakan strategis pencapaian pembangunan desa massamaturu adalah: 


\section{Bidang ekonomi kemasyarakatan}

a. Mengupayakan agar hasil produksi pertanian dan perkebunan tanaman pangan seperti padi, jagung dan palawija dapat meningkat dengan pemberian bantuan alat alat pertanian.

b. Mengupayakan agar hasil pengelolaan peternakan baik ternak kecil maupun ternak besar dapat meningkat dengan bantuan bibit dan penyuluhan.

c. Mengembangkan home industry dan usaha kecil menengah dengan memberdayakan kelompok tani dan badan usaha mlilik desa (BUMDES) dan memberikan bantuan modal usaha dan kredit bunga rendah.

d. Mengembangkan kemampuan pengelolaan pertanian dangan penyuluhan pertanian.

e. Pemenuhan kebutuhan saprodi bagi masyarakat petani miskin dengan memberikan bantuan modal usaha.

f. Menggeliatkan pendapatan masyarakat dengan perbaikan pasar desa.

g. Memperlancar transportasi perdagangan hasil pertanian masyarakat dengan perbaikan sarana dan prasarana inprastruktur desa.

\section{Bidang pendidikan}

a. Anak usia sekolah dapat mendapatkan fasilitas dan pelayanan pendidikan yang baik dengan pembangunan sarana inprastruktur sekolah.

b. Tingkat pendidikan masyarakat dapat ditunjang dengan Pemberian beasiswa bagi siswa SD, SMP, SMA yang berprestasi dan Pemberian bantuan bagi siswa lulusan SMA kejenjang yang lebih tinggi ( Kuliah )

c. Peningkatan pendapatan masyarakat dengan Pelatihan dan penyuluhan keterampilan khusus kepada masyarakat

3. Bidang kesehatan

a. Pelayanan kesehatan masyarakat dapat di jangkau dengan mudah dengan pembangunan puskesmas pembantu (PUSTU) dan posyandu di tiap tiap dusun

b. mencegah bibit penyakit pada musim hujan dengan pembangunan sarana pencegah banjir di musim hujan dengan Pembuatan Tanggul/Talud pencegah banjir

c. Memenuhi kebutuhan air bersih terutama bagi masyarakat miskin dengan pengadaan sumur bor di setiap dusun

d. Menumbuhkan dan meningkatkan kesadaran masyarakat tentang perilaku hidup sehat yang di mulai dengan kebersihan rumah dan lingkungan tempat tinggal dengan penyuluhan kesehatan

e. Memperbaiki perilaku masyarakat untuk tidak membuang kotoran sembarang tempat dengan pembuatan jamban di tiap rumah tangga.

4. Bidang sarana dan prasarana umum

a. Mengatasi masalah banjir yang sangat meresahkan masyarakat dengan Pembuatan tanggul penahan banjir, sanitasi /saluran air, pembuatan talud dan dekker plat

b. Memperlancar akses tranportasi umum dengan Pembuatan jembatan penyebrangan, pembukaan jalan baru, pengaspalan jalan raya desa, penimbunan jalan sertu, pembuatan talud jalan raya, dan pelebaran jembatan jalan raya desa

c. Memperbaiki administrasi pembagian wilayah desa dengan Pembuatan batas desa dan dusun

d. Memenuhi kebutuhan masyarakat umum deangan Pembangunan mesjid dan pembuatan kuburan umum dalam desa

e. Meninggkatkan perekonomian masyarakat dengan Rehabilitasi pasar desa

f. Menjaga mayarakat agar tetap kondusif dengan Pembangunan pos ronda di tiaptiap dusun.

\section{Bidang Pemerintahan dan} kelembagaan desa

a. Mempermudah pelayanan masyrakat dengan Pembangunan rumah jabatan kepala desa, gedung kelembagaan desa ( BPD, LPM, PKK )

b. Meningkatkan perekonomian masyarakat dengan Pembangunan kantor badan usaha milik desa ( BUMDES )

C. Meningkatkan kinerja aparat desa dan kelembagaan desa dengan pelatihan dan sosialisasi bagi aparat desa, Penambahan Anggaran Dasar Desa (ADD) dan UDD Desa Percepatan pelaksanaan

\section{Bidang kerohanian}

a. Mempermudah aktifitas kerohanian masyarakat Pembangunan mesjid dan 
perbaikan /rehabilitasi mesjid di tiap dusun

b. Meningkatkan dan mengaktifkan majelis taklim dengan Pembinaan dan pelatihan bagi majelis taklim

c. Meningkatkan pengetahuan dasar tentang agama dengan Pemberian bantuan bagi TK/TPA di semua dusun

\section{SIMPULAN DAN SARAN}

Dari hasil epenlitian disimpulkan: (1) Pola pembangunan yang dilaksanakan di desa Massamaturu mengunakan pola pembangunan yang bersifat bottom - up yang dibuat berdasarkan kebutuhan, keinginan dan permasalahan yang muncul di masyarakat kemudian di akomodasi pemerintah daerah maupun pusat sebagai mata program dalam perencanaan pembangunan yang ada di Desa. Penanggulangan kemiskinan di desa Massamaturu merujuk pada kondisi, karakteristik dan kebutuhan masyarakat dengan program-program yang meliputi Prudes, badan usaha milik Desa, Embung Desa dan raga Desa; (2) Pelaksanaan UU No.6 Tahun 2014 pasal 78 ayat (1) berdampak positif dan penurunan angka kemiskinan pertahun turun 3-4\% dengan merealisasikan kebijakan-kebijakan yang lebih mengarahkan kepada kesejahtraan masyarakat dengan program memberikan pelatihan menjahit, penyuluhan pertaniaan, membagikan bibit unggul, memberikan alat pertukangan dan pertanian bagi kelompok tani yang ada di desa dan dapat dirasakan bagi semua masyarakat dengan baik; (3) aktor pendukung dalam penaggulangan kemiskinan di desa Massamaturu di antaraya: arah kebijakan pembangunan desa, perencanaan pembangunan desa, starategi pembangunan desa dan starategi pencapaian pembagunan desa (bidang ekonomi, pertanian, pendidikan, kesehatan, sarana prasarana, pemerintahan dan kerohanian). Faktor penghambat sumber daya manusia masih rendah karena mayoritas penduduk desa Massamaturu adalah petani.

Berdasarkan hasil penelitian dan pembahasan serta kesimpulan yang telah dikemukakan, berikut ini adalah beberapa saran yang diharapkan dapat menjadi masukan dan bahan pertimbangan untuk penelitian selanjutya, adapun saran tersebut berikut ini: (1) Komitmen masing-masing perangkat desa dalam proses perencanaan dan penganggaran mengatasi masalah kemiskinan di desa; (2) Dalam proses penganggaran desa perlu memikirkan strategi penganggaran yang efektif sehingga tepat sasaran dalam realisasinya di masyarakat dengan baik dan benar; (3) Dalam proses perencanaan desa perlu memikirkan sinkronisasi program daerah dan desa agar dengan menggunakan pola bottom up sesuai dengan kondisi, karakteristik dan kebutuhan masyarakat sehinga kebijakan yang lahir berdasarkan partisipasi atau keterlibatan masyarakat, bukan lagi menjadikan masyarakat sebagai objek program, melainkan sebagai subjek.

\section{DAFTAR RUJUKAN}

Hikmat. 2004. Jaman Daulat Rakyat: dari Otonomi Daerah ke Demokrasi. Yokyakarta: Lapera Pustaka utama.

Inu Kencana, IGN. 2004 . Kemiskinan di Indonesia dan Program IDT. Jakarta: Centre For Strategic and International Studes.

Kuncoro. 1997. Hukum Pemerintahan Desa :Dalam Konstitusi Indonesia Sejak Kemerdekaan Hingga Era Reformasi. Malang: Setara Press.

Nugroho. 1995. Teori Pembangunan dan Tiga Dunia. Diterjemahkan oleh Tim Redaksi Gramedia. Jakarta: PT Gramedia.

PPs UNM. 2017. Pedoman Penulisan Tesis dan Disertasi Program Pascasarjana UNM. Universitas Negeri Makassar: PPs UNM.

Siti Fatimah. 2012. Pengantar Kesejahteraaan Sosial. Bandung: PT.Rafika Aditama.

Sumarto. 2003 .Utang, Kemiskinan dan Globalisai: pencarian Solusi alternatif. Yogyakarta: Lapera Pustaka Utama.

Sonntag et al. 2005. Pemberdayaan Masyarakat. Yogyakarta. Pustaka Pelajar.

Sondang P.Siagian . 1999 a. Ekonomi Pembangunan. Jakarta: Mitra wacana media. 
Phinisi Integration Review. Vol 2(2) Agustus 2019

Sondang P.Siagian. 2015b. Ekonomi Pembangunan Daerah. Jakarta: Mitra wacana media.

Siti Irene, A. 2011. Komunikasi dan Hubungan Masyarakat. Jakarta: PT. Bumi Aksara.

Suryawati. 2000 . Strategi pembangunan Dan Kemiskinan. Bandung: Rineka Cipta.

Undang- Undang RI nomor 6 tahun 2014 tentang Desa. PDF (www.dpr.go.id, Diakses 25 Agustus 2018).

Lampiran Undang- Undang RI nomor 12 tahun 2011 tentang Pembentukan Peraturan Perundang - Undangan, Teknik Penyusunan Naskah Akademik Rancangan UndangUndang, Rancangan Peraturan Daerah Provinsi, dan Rancangan Peraturan Daerah Kabupaten. PDF (www.dpr.go.id, Diakses 25 Agustus 2018). 